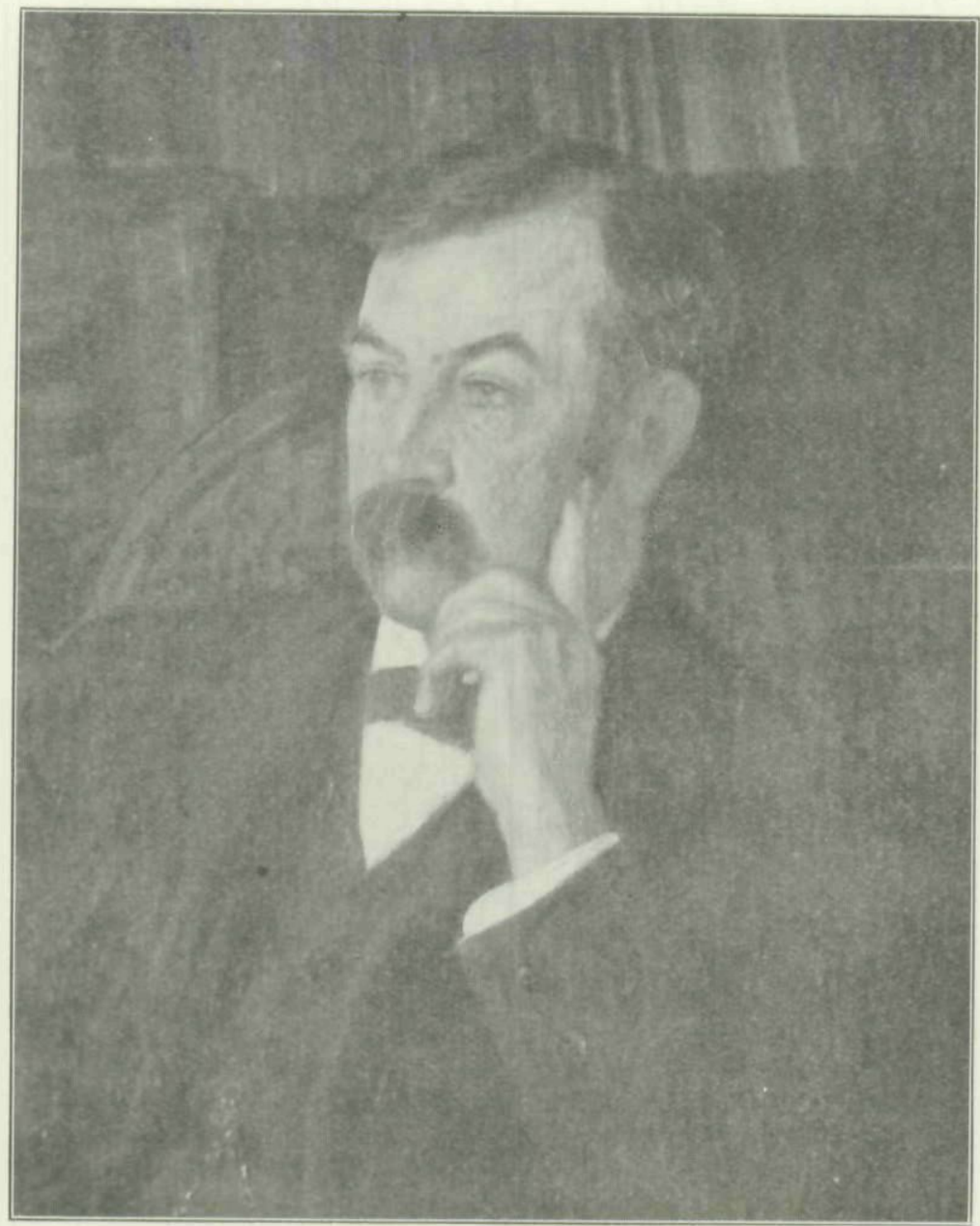

FRANK SPRINGER

From an oil painting by Louis Mayer, in the collections of the Historical, Memorial and Art Department of Iowa. 


\title{
SCIENTIFIC ACHIEVEMENTS OF FRANK SPRINGER
}

\author{
By Dr. Charles Keyes
}

A triple tiara of pre-eminence is reserved for few persons in this life. Seldom it is that one acquires wide reputation in some particular line of activity, much less a local acquirement of large success in business affairs, a national position in active profess.onal career, and global post in indefatigable scientific investigation. Yet this is the achievement of an Iowa son. The first two of these great accomplishments are properties of other states, but the third is a cherished possession of our own.

Frank Springer who passed on from this life on September 22, 1927 , at the ripe age of four score years, was personally almost unknown to Iowa people. Seldom was he in attendance at public functions concerning our state, from his distant home in New Mexico; and rarely, in fact, was he to be found in any of the gregarious gatherings of scientific men. Far from being a recluse, however, he was a public figure of no inconsiderable prominence, and he was busiest of men all through life.

With large business interests, and with an extensive law practice of great responsibilities, his scientific work necessarily suffered at times and it became more in the nature of mental relaxation from the strenuous affairs of life. Nevertheless, his accomplishments in paleontology were of no mean proportions for they ranked rather with those of the great Hall, Cope, and Marsh for copiousness rather than with those of any other of his contemporaries. The dozen sumptuous monographs on the erinoids, and the hundred-odd shorter memoirs, amply attest the tireless, plodding industry of this lawyer and business man in the scientific field.

It is hardly necessary in this connection to dwell upon the varied gifts of this favored son of the Iowa prairies-how, taking Horace Greeley's famed advice, he goes forth into the nascent West, literally with all his worldly goods in his carpetbag, into the New Mexico wilderness when all there was true "Injun country"; how he finally establishes himself in a large and lucrative 
law practice, rising to a commanding position at the bar, and becoming one of the founders of a great new state, as his father before him was in Iowa; how he builds the great Eagle Nest dam on the Rio Cimarron for reclaiming an immense tract of desert, a feat which now only our government indulges in; how he gets control of a huge Spanish land grant of a million acres, one of the private principalities which old Spain erected upon her northern frontier to guard her Mexican possessions against the encroachments of the United States; and how that vast tract, with the help of Orestes St. John, another of Iowa's distinguished geological sons, turns out to be coal land; and how is financed a railroad, 150 miles long, to bring into market from these grant lands the largest tonnage of coking coal under single ownership in the United States. The marvel of it all is how any man of affairs of such moment could still find time to delve long and patiently into the dead field of paleontology and throw out to geologists results equal in volume to any of those of his contemporaries, and surpassing the most voluminous of them in refineness and lasting quality.

Frank Springer was born June 17, 1848, at Wapello, Iowa, thirty miles north of Burlington. His father was Judge Francis Springer, one of the leading lawyers of his day in the state, who was a delegate to and president of the State Constitutional Convention of 1857. His mother before her marriage was Nancy R. Coleman. Young Springer's early education was obtained chiefly in the public schools of his home town, and afterwards at the Iowa State University, from which institution he was graduated in 1867. Entering the law office of the Hon. Henry Strong in Burlington he was admitted to the bar in 1869, and practiced his profession in that place for four years.

The youth Springer acquired his taste for scientific study while yet a student in Iowa University, as a pupil of Professor Gustavus Hinrichs, with whom a warm and intimate friendship grew up and to whose influence, instruction and encouragement he in later years often expressed his great indebtedness. His especial interest in paleontology dates from a lecture and field excursion given to the students of the University by Professor Louis Agassiz. The personal charm of Agassiz and his unrivaled faculty of explanation fired the mind of the college student with 
desire to understand the science as presented by this great exponent.

At this time the facilities for geological study and instruction in Iowa University were of the most meager description: but in 1866 the headquarters of the State Geological Survey, then recently established with Doctor Charles A. White as the head, were opened at the University, and the collections were brought there for study. Thanks to the kindness of Doctor White and his chief assistant, Orestes St. John, Mr. Springer was given free access to the collections and the scientific libraries, and he became a student of geology and paleontology outside of his regular university course. A strong personal friendship was formed with both of these gentlemen, and when they went off into the field the following season Springer was left in charge of the state geologist's quarters and collections. There he passed all his spare time studying by himself until his graduation.

During his last years at the University young Springer collected plentiously of the Devonic fossils from the Iowa City 1egion. After leaving the University he spent considerable time in the field investigating on his own account the Early Carboniforous rocks around his home in Louisa County. It was here that he unearthed a remarkable deposit of fossil fish remains, many of which were described by St. John in the Illinois reports. During the preparation of these descriptions he visited the Illinois State Museum at Springfield, where he was also given access to the extensive private collections of Professor Worthen, the then state geologist.

At length locating in the law at Burlington the rich crinoidal faunas of that famous locality naturally attracted his attention, and soon he became an ardent collector, gradually accumulating a large and valuable assortment of material. Here he was not iong in falling in with Wachsmuth, Thieme, Worthen and the rest of them and shared much of their enthusiasm, often, it may be surmised, to the neglect of his law business. But the association with Wachsmuth continued for thirty years and only terminated with the latter's death. From collecting together they soon began to study together and thus were laid the foundations of the collaboration which culminated in the two great monographs.

In the winter of $1872 \mathrm{Mr}$. Springer visited Cambridge, Massa- 
chusetts, and was given by Professor Agassiz access to the splendid collection of the Museum of Comparative Zoology. It was chiefly owing to the personal encouragement received from Agassiz at this time that he was led to keep up his paleontological interest after leaving Burlington, which he was soon to do.

In 1873, induced by the proposed extension of the Atchison, Topeka \& Santa Fe Railway to the Rio Grande and the Pacific coast, Springer removed to New Mexico, settling first at Cimarron, in the northeastern corner of the territory, and later making Las Vegas his home. Here in the following year he met Orestes St. John, who was out on a scouting trip for the railroad, and together the two made a reconnoissance of the Raton coal field, much of which was found to be included in the old Spanish land grant of Mrxwell.

Fortunate in early acquiring independent means he is able to keep collectors in the field more or less continuously or as occasion requires, to engage artists for his plates, buy up local collections which seem desirable, and visit and study in the museums both at home and abroad. During the first two decades of his serious devotion to strictly scientific work his partner in the crinoid industry, Charles Wachsmuth, does most of the literary preparation. So long as the partner colleague lives Springer spends his summers regularly in Burlington where the two put up a fine fireproof building to house their priceless collections.

Despite the long strenuous business days in the new field of endeavor Springer's thoughts go back frequently to the Burlington crinoids, perhaps guided by letters from his old home. At any rate he manages to arrange matters so that he may spend his summer vacations back in Iowa in company with Wachsmuth. During this first decade he succeeds in bringing out several short memoirs; and he and Wachsmuth together publish the Revision of the Palaeocrinoidea, in four parts, which serves in reality as a preliminary review of the entire crinoidal realm preparatory to the launching of the monographs.

In the meanwhile his legal training back in Iowa bears him good fruit in the nascent state of New Mexico; and it is not many years before he finds himself in command of an extensive and important law business. In time his practice comes to be chiefly the larger cases before the United States Court of Claims, the 
Territorial Supreme Court, and the Supreme Court of the United States. Mr. Springer's successful conduct of a series of cases of large magnitude in the United States Supreme Court, involving some of the largest property interests in the state, brings him to the front rank of the New Mexican bar, where his position as one of its most distinguished members is now fully recognized throughout the Southwest.

Doctor Springer's interests were varied. He was twice member of the Territorial Legislature, which was the voluntary extent of his political career. He held many posts of trust both in state and in business. His services as patron of the School of American Archeology at Santa Fe are widely known. Elected to membership to numerous of the learned societies both at home and abroad he was also the recipient of academic honors-the degrees of Doctor of Science from the George Washington University in 1921, and the degree of Doctor of Philosophy from the German university at Bonn in 1924. In conferring the last mentioned honor by the Rheinische Friedrich Wilhelms University it was "as eminently successful investigator of fossil Crinoidea; author of a reliable treatise on the Palæocrinoidea; disinterested promoter of scientific research; especially in recognition of the fact that all his scientific accomplishments have been gained outside of his main calling in life."

Doctor Springer peacefully passed away at the home of his daughter in Overbrook, near Philadelphia, on September 22, 1927.

It is an incident worthy of more than passing notice to mention that Springer's last years were also his most productive ones. Besides seeing the monograph on the Siluric Crinoids out, he published three other important memoirs, rather more than the usual number for him. He worked with zeal unabated to the very day of his demise. At four score years of age he put forth more than his normal annual average of published contributions to knowledge. The reason therefor mayhap be gathered from a public message which he gave out at home a decade before his final summons, on the Secret of Keeping Young.

The scientific results of Wachsmuth and Springer, and latterly of Springer alone after the demise of his colleague, are many, varied and important. They form a vast storehouse of facts and information for those who come after and who wish to use the 
data for biotic and stratigraphic purposes, for these fields are untouched by either of our systematists and they are still virtually virgin fields. The scope of the different monographs is perhaps best appreciated by reference to some of the more striking features of each. Were it not for the overshadowing nature of these large works the hundred-odd minor memoirs might profitably come in for notice and analysis. The monographs deserving of especial notice are the Revision of the Palaeocrinoidea, North American Crinoidea Camerata, in three volumes, Uintacrinus, Its Structure and Relations, Scyphocrinus and Its Bulbous Root, Camarocrinus, Crinoidea Flexibilia, in two volumes, and American Silurian Crinoids.

All in all the systematic description, classification and illustration of the ancient fossil crinoids is the most conspicuous unaided effort of the kind ever undertaken in this country. It is truly a colossal contribution to our knowledge of crinoidal life of the past. Accomplishment of this great work covers a period of fifty years.

When the Revision of the Palaeocrinoidea first came out the chief embarassments met with at the outset are well explained by a single paragraph taken from the introduction, which sounds the keynote for all subsequent investigations. "In attempting to make a systematic classification of the Palæocrinoids into families and genera, we encounter the difficulties which usually confront us when we undertake to ascertain and define divisions as they occur in nature. We may readily recognize in some groups of fossils certain broad characters by which it seems natural and satisfactory to bring them together, and we generally find in the characteristic types of the respective groups an association of other characters by which they appear sharply marked; and so long as we have to deal with typical forms in isolated specimens or groups the work is simple enough. But when we begin to investigate large collections and in a measure to study comparatively all the known material from specimens or descriptions we find these subjects bristling with perplexing questions. Types are found to shade into one another, characters are commingled through processes of transition, which sadly interfere with the the nice definitions we think we have worked out. How to deal with such forms has always been a troublesome question with 
naturalists, and the diverse methods of treating it have given rise to much confusion.

"We have found it especially perplexing in endeavoring to define the genera of the Crinoids. We find, for instance, two groups each embracing a number of species and we discover general characters which nicely separate them. Further research presently reveals to us certain forms including perhaps several species which, while agreeing with the one group in most of the characters, persistently differ from it in some one feature and possibly in this feature they agree with the other group. The question then arises, what is to be done in cases when there are aberrant forms, departing from one type in the direction of another, and blending the characters of the two. Are we to say that our groupings are worthless, and the two must be thrown into one? This produces confusion; and stands in the way of systematic study; and besides we shall then be no nearer the truth, for we shall doubtless find a similar relation between the group thus formed and some other one which will in turn demand a similar consolidation. On the other hand, shall we stand by the distinctions that we have discovered and range our transitional or aberrant forms into subgroups by themselves, and designate them by proper appelations? We are clearly of the opinion that the latter, judiciously pursued, is the true course, both in regard to convenience of study and to facilitate the discovery of a natural classification.

"Without entering into any prolix discussion over the value of these or any other groups as expressions of actual divisions in nature we purpose to adopt this method of treatment and to recognize subgenera or subgroups of whatever dignity as the facts seem to warrant. In so doing we find that it is decidedly preferable to give each group a name by itself, and consider it as standing alone in its proper rank and not to name it parenthetically as a mere adjunct to the parent group. If we err on the side of too narrow distinctions this will only lead to renewed researches and ultimately to the truth."

In $1890 \mathrm{Mr}$. Springer went to Cambridge and placed before Mr. Alexander Agassiz, the then director of the Museum of Comparative Zoology which his father had founded, the original drawings for the proposed monograph so far as then completed together with an outline of the plan of the work. After examining them closely Mr. Agassiz offered to undertake the publication 
of the volumes and place them in the series of the memoirs of the Museum of Comparative Zoology. Further, he put at the disposal of the authors the entire collections of crinoids belonging to the Museum with liberty to remove to Burlington for study whatever portions of them which might be needed.

The monograph was essentially a presentation of the data upon which rests the systematic arrangement of the stemmed echinoderms. It was of great interest at the time to know that the advancement in an understanding of the crinoidal group was made almost wholly from the paleontological side; and that the results were so speedily accepted virtually without change by most if not all of the most eminent students of the living forms. Although today nearly extinct, in past geological ages they were, as is well known, among the most prolific forms of life. On account of their peculiar structure unusually fine opportunities were afforded for the solution of morphological problems, and full advantage was here taken. Upon so firm a foundation did the classification of the crinoids as prepared by these authors rest that it was evident that it would probably not require any very radical changes for a long time to come.

Concerning the major subdivisions of the stemmed echinoderms three groups were recognized: cystids, the blastoids and the crinoids. These were regarded as groups of equal taxonomic rank. The forms of the first group were earliest in point of time, lowest in taxonomic position, and the ancestral types of the other two groups. The crinoid type itself is of course, a very ancient one, dating from early Cambrian times in which period it was already in a high stage of development. By Ordovicic times the Cystidian features had almost completely disappeared. The crinoidal group is quite remarkable for reason of the persistence it has shown in preserving its pentamerous symmetry; and although the introduction of an anal plate sometimes so disturbed that symmetry as to well nigh produce a distinct bilateral arrangement the primitive plan was finally permanently preserved.

One fundamental morphological feature which the monograph brought out was implied by the abandonment of the former classification of the crinoidal type into the Neocrinoidea and Palæocrinoidea, the two primary groups of crinoids which were formerly almost universally recognized. In their stead were made 
three principal subdivisions: Inadunata, Camerata and Articulata. It was a quite noteworthy circumstance that this ternate grouping of the crinoids was essentially the same separation that was originally proposed by Wachsmuth more than twenty years previously, but after being compelled by students of recent forms to abandon it and to substitute others, a careful resurvey in the light of the latest discoveries amongst all crinoids both living and iossil clearly showed that the main divisions first suggested were essentially valid and were applicable to all known forms.

Then, too, the presentation of the criteria for separating the crinoids into orders were most important as well as simple. They were (1) condition of the arms, whether free above the radials, or partly incorporated in the calyx; (2) mode of union between the plates of the calyx, whether movable or rigid; and (3) growth of the stem, whether by new plates beneath the proximal ring of the calyx or beneath the top stem joint.

The beautiful memoir on Uintacrinus, its Structure and Relations was based upon some remarkable groups of specimens discovered in western Kansas the like of which had never before been seen. After publication of this monograph fine large slabs covered with hundreds of crinoids were presented to some of the principal museums of the world. In this country these unmatched rock plates were donated to the Museum of Comparative Zoology at Cambridge, the National Museum in Washington, the American Museum of Natural History in New York, the Museum of Chicago University, and the Museum of the Iowa State University at Iowa City. In Europe repositories for similar magnificent slabs of crinoids were made of the British Museum in London, and the Museum of Berlin.

In acknowledgment of the gift to the American Museum the directors issued a special publication giving a full account of the acquisition illustrating it with two plates. At the Museum of Comparative Zoology the director, Mr. Agassiz, was so pleased that he caused the one sent there to be mounted under a plate glass, four by eight feet in size, and hung on the wall just inside of the front entrance of the building in order, as he said, every one who entered the door might see it.

Scyphocrinus and Its Bulbous Root Camarocrinus solved one of the great mysteries of the crinoid realm. The Scyphocrini were giants of their day and race. They resembled somewhat 
gooseberry bushes swaying to and fro on the bottom of the epicentinental seas. It had never been found complete. Different parts of it, as it now turns out, had been given different names. It was Springer's good fortune to run down the mystery and find the various parts together. These crinoids were unearthed in the early Devonian rocks of Missouri. They presented a new phase of crinoid morphology in that the calyx was lobed by the protuberance of the inter-radial areas instead of the radial.

Concerning the great monograph on the Crinoidea Flexibilia, which appeared in two large volumes, one comprising eighty plates, several features stand out prominently. These forms are the rarest types of crinoidal life. Mainly for this reason they are generally little understood. By dint of industrious accumulation of materials covering a period of half a century, the means are found to evolve a classification of them which seems to be widely acceptable to students. This investigation especially clears up many doubtful points relative to the genetic relationships of this long, little known group of organisms. Thus again, for the nth time, order is brought out of confusion.

The fact that the Flexibilia were the rarest of crinoidal forms itself was incentive enough that they should receive special consideration. It was, as Springer himself observed, a fresh illustration of the growth of knowledge that the division of the Crinoidea which formed the subject of the memoir in question was not known at all to the earlier systematic writers who treated of the class, neither to J. S. Miller with whose epoch-making monograph the systematic study of the crinoids as a group began a century ago, nor to Johannes Mueller whose masterly researches upon the anatomy of the Echioderms twenty years later laid the foundations for future investigations upon their structures. The magnitude of the group as now understood is indicated somewhat by the size of the Springer monograph, and the progress above mentioned is further exemplified by the manner in which the subject expanded under Springer's hands.

When Dr. Springer first began the study of the Flexibilia after the death of Wachsmuth the collections were relatively small, only desultory notes were in hand, only a few of the illustrations had been prepared, and the plan was a part of a more ambitious one of working up the two groups remaining after the 
Camarata. Of these it was supposed that the Flexibilia would be a relatively minor undertaking, all falling into the compass of a single volume.

It soon became evident, however, that the plan of restricting the detailed investigation of this group to its American representatives alone, as was done in the treatise on the Camarata by Wachsmuth and Springer, was unsatisfactory in many respects, and it was decided to modify the original scope by including all known forms in the world.

The American Silurian Crinoids had its inception in a desire to record the new finds since the publication of the Camarata monograph thirty years previously, and to put the American fauna on a level with that of Sweden and England. It was Doctor Springers' last effort.

Most fortunately for all concerned Springer lived to complete his last great monograph, the one on the American Siluri Crinoids and the final one of the series originally outlined in the Revision more than forty years before. Although confined to his room for the last few years with his fatal heart malady he works on cheerfully, determinedly, hopefully and lingers on in the full plenitude of his mental powers to see the work off the press a few weeks before his demise. Fully realizing that it is his last effort and so thankful that he is spared to finish it, he appends his swan song, chiefly a recounting of the events transpiring at the presentation function to the state when the people of New Mexico in visible expression of their appreciation of him, gave the beautiful bronze bust of himself, the creation of the famous sculptor Scarpitta.

Accomplishments of this kind impress us with the conviction that the large achievements of mankind are not all wrought in marble monument. Greatest strides in human progress are oft indited in simple character on perishable papyrus roll.

Marvelous circumstance is it that the one monumental production in a principal branch of pure science during a quarter of a century and of global scope should emanate from the mind of a demure Iowan far removed from the usual centers of consultation and constantly occupied with business and professional affairs of large moment. Our state pride could have no nobler outlet than when its intellectuality bursts provincial bounds and takes on world-wide aspect. 
Copyright of Annals of Iowa is the property of State of Iowa, by \& through the State Historical Society of Iowa and its content may not be copied or emailed to multiple sites or posted to a listserv without the copyright holder's express written permission. However, users may print, download, or email articles for individual use. 